\title{
MANAGING LAWNS ON HEAVY SOILS
}

\author{
M. Ali Harivandi, Environmental Horticulture Advisor, San Francisco Bay Area; and \\ Victor A. Gibeault, Environmental Horticulturist, Cooperative Extension, University of California, Riverside.
}

This publication addresses the fundamentals of lawn management on heavy (clay) or compacted soils. Irrigation, aerification, fertilization, mowing, and pest control require special consideration when lawns are to be maintained under these conditions.

\section{IRRIGATION}

Deep, less-frequent irrigations are preferable to shallow, frequent ones because deep irrigations encourage deep rooting, increase the total soil moisture available for plant use, and leach accumulated salts. Deep irrigations that are spaced far enough apart to allow the soil surface to dry reduce the likelihood of infection by disease, soil compaction, and invasion of turf by shallowrooted annual weeds. To make deep, infrequent irrigation possible on heavy or compacted soil, it is often necessary to aerify the soil (see below) to allow water to move more freely into it.

For proper lawn inrrigation, it is essential to know the delivery rate (inches $[\mathrm{cm}] /$ hour) and the distribution pattern of sprinklers. To estimate the delivery rate, place several small, flat-bottomed cans of equal size at 5 -foot $(1.5 \mathrm{~m})$ intervals on lines radiating from a sprinkler head. Operate the sprinklers for a planned length of time, then measure the water in the cans and calculate the average water depth per can. The following example shows how to use this average to calculate the proper length of irrigation time with your system. If, after 20 minutes of operation, the total amount of water in 10 cans around a sprinkler head is $2 \frac{1}{2}$ inches (6.4 $\mathrm{cm})$, the average depth per can is $1 / 4$ inch $(.64 \mathrm{~cm})$. To deliver $1 / 2$ inch $(1.28 \mathrm{~cm})$ of water, this sprinkler must operate for 40 minutes. Remember, however, that heavy soils have low water infiltration rates: water penetration into the turf root zone is typically $1 / 2$ inch (1.28 $\mathrm{cm})$ per hour or less on heavy soils. Water applied faster will run off the surface or puddle in low spots instead of soaking in uniformly. Water infiltration rate is therefore as critical as delivery or application rate.

To manage a low infiltration rate, turn off the sprinklers as soon as runoff occurs. Resume and complete irrigation only when previously applied water has percolated to deeper layers of the soil. Sprinklers may need to be run for a few minutes several times consecutively to apply the required water. Aerifying the soil (see below) helps improve the infiltration rate; in particular, lawns on slopes may benefit from aerification because the holes dug during aerification will trap water that would otherwise have run off.

A weekly application of 1 to $1 \frac{1}{2}$ inches $(2.5-3.8 \mathrm{~cm})$ of water during summer months is generally adequate for lawns if there is no runoff. Water requirements differ depending on location. During extended hot spells, two irrigations per week may be necessary. Lawns on very shallow soils (less than 8 inches $[20 \mathrm{~cm}]$ ) or on slopes may require more frequent irrigation with less water per irrigation.

To reduce evaporation loss, it is best to irrigate lawns early in the morning, generally between 2:00 a.m. and 8:00 a.m. Avoid late-afternoon and evening irrigationdamp soil promotes infection by disease.

\section{AERIFICATION}

Heavy (clay) or compacted soils benefit significantly from aerification. Lawn soil compaction is caused by continued foot and equipment traffic, which presses soil particles together. The remedy for compacted soil under turfgrass is to remove soil cores that are $1 / 4$ to $1 / 2$ inch $(0.6-1.3 \mathrm{~cm})$ in diameter and approximately 3 to 4 inches $(7.5-10 \mathrm{~cm})$ deep. This practice is called "aerifying" or "coring." For small lawns, a hand aerifier, consisting of hollow tubes on a stirrup pushed into the soil by foot, is sufficient. For large or extremely compacted lawns, a machine-driven aerifier can be rented, or the aerification can be performed by a lawn maintenance company.

Aerification is an effective method for correcting poor water penetration because poor penetration is usually caused by physical rather than chemical characteristics of the soil. Because of this, soil amendments applied to existing lawns rarely improve the infiltration rate. Even gypsum, often sold for "softening" hard soils, is useful only in sodic (alkali) conditions in which soils or water are relatively high in sodium. Adding organic matter prior to planting a new lawn, however, can improve the physical structure of heavy soils, thus improving infiltration.

\section{FERTILIZATION}

Turfgrasses grow best with adequate nutrition. Nitrogen $(\mathrm{N})$, phosphorus $(\mathrm{P})$, and potassium $(\mathrm{K})$ are the nutrients needed in the largest quantities by turf-

\section{University of California - Division of Agriculture and Natural Resources Publication 7227}


grasses. In most California soils, phosphorus and potassium are naturally present in adequate amounts. However, to ensure that both these nutrients are adequately available to the turfgrass, it may be desirable to make at least one application of a complete fertilizer (one containing $\mathrm{P}$ and $\mathrm{K}$ as well as $\mathrm{N}$ ) annually. The percentage of each nutrient is shown on every bag of fertilizer as the ratio N-P-K. A 20-15-5 fertilizer, for example, contains 20 percent $\mathrm{N}, 15$ percent $\mathrm{P}$ (phosphoric acid), and 5 percent $K$ (potash). Nitrogen must be applied on a regular basis for optimum grass growth. Moderate application of $\mathrm{N}$ at regular intervals is the key to healthy, dense, green turf.

Cool-season grasses (such as turf-type tall fescues, Kentucky bluegrass, and perennial ryegrass) grown on heavy soils need 4 to 6 pounds of $N$ per 1,000 square feet $(18-27 \mathrm{~g} / \mathrm{sq}$. m) of lawn per year. Apply no more than $1 / 2$ to 1 pound of $N$ per 1,000 square feet $(2.3-4.5$ $\mathrm{g} / \mathrm{sq}$. $\mathrm{m}$ ) per application. Use the percentage of $\mathrm{N}$ in the fertilizer to compute the total amount of fertilizer to be applied. For example, it would take 5 pounds $(2.3 \mathrm{~kg})$ of 20-15-15 fertilizer to apply 1 pound of $\mathrm{N}$ per 1,000 square feet. Applications should be made in spring and fall only. Warm-season grasses (such as Bermudagrass) should be fertilized monthly during their growing season (while the grass is green), with no more than $1 / 2$ to 1 pound of $\mathrm{N}$ per 1,000 square feet $(2.3-4.5 \mathrm{~g} / \mathrm{sq} . \mathrm{m})$ per month. When fertilizing, consider the following:

-Apply dry fertilizers only when grass is dry. Use liquid fertilizer as directed by the manufacturer.

- Distribute fertilizer uniformly. Dry fertilizer may be applied by a spreader or broadcast by hand. Wear gloves if spreading fertilizers by hand. Spread one-half the total amount while moving in one direction, then spread the balance while moving in the opposite direction.

-Do not overfertilize.

\section{MOWING}

Cutting grass too short or mowing too frequently reduces lawn vigor and increases weed invasion. Turftype tall fescue lawns should be cut $1 \frac{1}{2}$ to 3 inches $(3.8-7.5 \mathrm{~cm})$ tall. Kentucky bluegrass and perennial ryegrass lawns should be cut $1 \frac{1}{2}$ inches to $2 \frac{1}{2} 2$ inches $(3.8-6.4 \mathrm{~cm})$ tall. Bermudagrass lawns are best maintained at $1 / 2$ to 1 inch $(1.3-2.5 \mathrm{~cm})$. Lawn appearance is greatly affected by mower sharpness. Grass blade tips torn by a dull mower will leave a pronounced, light brown "haze" on the turf surface. Tearing also makes grass more susceptible to infection by disease than does a clean cut.

Lawn clippings should be left on lawns that are mowed regularly and at fairly short intervals. This practice, known as "grasscycling," saves time and reduces green waste. Under these conditions, clippings dry and decompose relatively quickly, adding nutrients to the soil. If the lawn is not mowed frequently enough, however, the thick layer of clippings left after mowing decomposes slowly. Undecomposed clippings can smother underlying grass and contribute to the development of thatch (a layer of organic matter at the soil surface). Thick thatch is a physical impediment to air and water movement into the soil, compounding a problem already common in heavy soils. Successful grasscycling depends on the following rule of thumb for mowing: do not cut more than one-third of a lawn's leaf blades at each mowing. That is, if the mowing height chosen for a lawn is 2 inches $(5 \mathrm{~cm})$, the lawn should be mowed before the grass grows taller than 3 inches $(7.5 \mathrm{~cm})$.

\section{DISEASE AND WEED CONTROL}

Diseases. Several plant diseases attack home lawns. Proper irrigation is the most important factor in preventing or reducing disease problems in lawns on heavy soils. If plant diseases become a problem, they can be controlled with the several registered fungicides and insecticides that are available.

Weeds. Proper irrigation, fertilization, mowing, and periodic hand weeding will control most lawn weeds. However, extensive weed infestation may require chemical control. Selective herbicides are available for treating broadleaf weeds in grass lawns. Weedy grasses in grass lawns can be removed by spot treatment with nonselective herbicides or by the use of preemergence herbicides on annual grassy weeds.

\section{Precautions for using chemical pesticides:}

- Follow label directions and precautions when applying pesticides.

- Prevent chemical sprays from drifting to nearby ornamentals.

-Apply chemicals only to healthy, actively growing grass.

The University of California, in accordance with applicable Federal and State law and University policy, does not discriminate on the basis of race, color, national origin, religion, sex, disability, age, medical condition (cancer-related), ancestry, marital status, citizenship, sexual orientation, or status as a Vietnam-era veteran or special disabled veteran. The University also prohibits sexual harassment. Inquiries regarding the University's nondiscrimination policies may be directed to the Affirmative Action Director, University of California, Agriculture and Natural Resources, 300 Lakeside Drive, 6th Floor, Oakland, CA 94612-3560; (510) 987-0096.

76-pr-5/97-SB

ISBN 978-1-60107-019-7 